\title{
Prevalência de Distúrbios Osteomusculares Relacionados ao Trabalho (LER/DORT) em profissionais Cabeleireiras de Institutos de Beleza de dois distritos da cidade de São Paulo*
}

\author{
Prevalence of work-related musculoskeletal disorders \\ (WRMD) among hairdressers of Beauty Parlour in two \\ districts of the city of Sao Paulo
}

\begin{abstract}
Gisele Mussi
Mussi G. Prevalência de Distúrbios Osteomusculares Relacionados ao Trabalho (LER/DORT) em profissionais Cabeleireiras de Institutos de Beleza de dois distritos da cidade de São Paulo [tese].Saúde, Ética \& Justiça. 2005;10(1/2):54-5.

RESUMO: Uma das atividades pouco estudadas no âmbito da Saúde do Trabalhador no Brasil é a dos profissionais de Institutos de Beleza, função historicamente vinculada ao gênero feminino e que foi sujeita a grandes mudanças no processo de trabalho ao longo dos últimos anos. Nesse estudo, optou-se por analisar o trabalho das cabeleireiras, pois estas profissionais estão sujeitas a diferentes agravos à saúde devido aos fatores de risco inerentes às suas atividades. Os objetivos do estudo foram verificar a prevalência dos Distúrbios Osteomusculares Relacionados ao Trabalho (LER/DORT) em cabeleireiras por meio de relatos de sintomas, caracterizar as regiões anatômicas mais acometidas e identificar e analisar os fatores de risco para LER/DORT existentes no trabalho dessas profissionais. Foi utilizado um estudo epidemiológico transversal e também o embasamento teórico do método de avaliação da situação de trabalho e repercussões na saúde, desenvolvido pela teoria da Ergonomia Francesa, para se discutir determinadas associações entre condições de trabalho e morbidade referida. Foram estudadas, no período de abril de 2002 a fevereiro de 2004, 220 cabeleireiras e auxiliares que trabalhavam em Institutos de Beleza localizados nos distritos de Pinheiros e Jardim Paulista da cidade de São Paulo. Identificou-se, a partir de relato de sintomas, uma prevalência de LER/DORT de 70,5\%. A localização corporal mais freqüente de relato de sintomas para LER/ DORT foi ombro $(48,6 \%)$, seguida pelo pescoço $(47,3 \%)$ e coluna $(38,6 \%)$. Verificou-se que os fatores de risco associados à ocorrência dos Distúrbios Osteomusculares Relacionados ao Trabalho (LER/DORT) em cabeleireiras estavam relacionados com: a) Fatores de Incômodo e Fadiga no Trabalho (referentes à organização do trabalho e aos aspectos psicossociais do trabalho) sendo que, após análise fatorial, o único dos fatores resultantes que teve significância estatística foi o que agrupava as variáveis Falta de reconhecimento no trabalho e Postura desconfortável no trabalho (ORaj =3,54; $\mathrm{p}=0,004)$; $b$ ) Posturas assumidas durante a realização das atividades - Não sentir conforto no corpo/pescoço/ombros enquanto trabalha $(\mathrm{ORaj}=2,78$; $\mathrm{p}=0,004)$; c) Tempo de profissão acima de 15 anos (ORaj $=3,04 ; \mathrm{p}=0,022)$. Identificou-se, por meio de relato de sintomas e da análise ergonômica do trabalho, que os fatores de riscos ocupacionais associados ao desenvolvimento de LER/DORT em cabeleireiras, confirmam os riscos já descritos na literatura referentes a outras atividades, ou seja, aqueles relacionados aos fatores biomecânicos, organizacionais e psicossociais do trabalho.
\end{abstract}

DESCRITORES: Saúde ocupacional, Transtornos traumáticos cumulativos, Ergonomia (Saúde ambiental), Riscos ocupacionais, Salão de beleza.

\footnotetext{
* Tese de doutorado apresentada à Faculdade de Medicina da Universidade de São Paulo. Orientador: Prof. Dr. Nelson da Cruz Gouveia
} 
Mussi G. Prevalence of work-related musculoskeletal disorders (WRMD) among hairdressers of Beauty Parlour in two districts of the city of Sao Paulo [tese]. Saúde, Ética \& Justiça. 2005;10(1/2):54-5.

ABSTRACTS: An activity poorly studied in Occupational Health in Brazil is the work of professionals in Beauty Parlours. This occupation is historically linked to the female gender and in the past years has been through huge changes in its operational process. In this study it was decided to analyze the job of hairdressers since these professionals are under different health hazards due to risk factors related to their activity. The objectives of the study were to assess the prevalence of WRMD among hairdressers through reported symptoms, to characterize the most injured anatomic regions, and to identify and analyze the risk factors for WRMD present in the activities of these professionals. A cross-sectional study was employed together with the theories of the method for evaluation of the work situation and its consequence on health developed by the French Ergonomics, in order to discuss certain associations between working conditions and reported morbidity. Between April 2002 and February 2004 a total of 220 hairdressers who worked in Beauty Parlors in the districts of Pinheiros and Jardim Paulista were studied. A prevalence of WRMD of $70,5 \%$ was found. The body region most reported with symptoms of WRMD was shoulder (48,6\%), followed by neck $(47,3 \%)$ and spinal column $(38,6 \%)$. It was noted that the risk factors for WRMD in hairdressers were related to: a) Annoying Factors and Fatigue at Work (connected to the work organization and the psychosocial aspects of the work) that after factorial analysis the only remaining factor statistically significant was the one that contains the variables lack of recognition at work and uncomfortable position at work.

KEY WORDS: Occupational health, Cumulative trauma disorders, Human engineering, Occupational risks, Beauty aesthetics centers. 